\title{
Fascism studies (and the 'Post-Fascist' era): an ideal meeting ground?
}

\author{
Nigel Copsey \\ School of Arts and Media, Teesside University \\ E-mail: N.Copsey@tees.ac.uk
}

As a historian of fascism's recent manifestations, I am acutely aware of the continuing and rather unfortunate division between historians and political scientists that still obtains in the field of fascism studies. "Most political scientists", as Roger Eatwell put it some time ago, "use the term 'fascism' in the contemporary context within a rigid inter-war template" (Eatwell 2004, 6). Despite the laudable attempt of Roger Griffin and others to draw attention to fascism's inherent protean quality, little has changed in the intervening period. Indeed, when it comes to the contemporary extreme right, few political scientists would even recognise the relevance of 'fascism studies' to their concerns, preferring to deploy neologisms such as 'radical right-wing populism' instead. Their field is not 'fascism studies' but 'radical right-wing populism' studies, a field that is concerned with the plethora of party-political organisations of authoritarian, nativist and populist type that have become increasingly embedded within Europe's contemporary political landscape.

If historians are more open to an appreciation of fascism's capacity for creative mutation in the period since 1945, political scientists are too ready to invoke the adjective 'new' when they speak about the contemporary extreme right. Of course it would be wrong to trace the ideological tradition of the contemporary extreme right only to fascism. But temporally focused on the present-day, political scientists are drawn far too readily to novelty, and pay insufficient attention to ways in which contemporary fascists recalibrate, conceal and supplement their fascism in the 'post-fascist' era. "The time has come", one political scientist has written, "to evaluate the radical right-wing in Europe based not on its ties to a Nazi past but based on the changes it realizes in a dynamic present" (Williams 2006, 9). Yet such an approach threatens to consign fascism to a museum.

In 1968, the historian Stuart Woolf $(1968,4-5)$ already saw in the study of fascism an "ideal meeting ground" for historians and political scientists (as well as sociologists and economists). Across recent years a flurry of inter-disciplinary 
studies has deepened our understanding of inter-war fascism further still, and yet the same can not necessarily be said for our understanding of fascism in contemporary times. For sure, we need greater interrogation of the continuities between historical fascism and contemporary manifestations. Admittedly, the historical contexts are different, but if we are to succeed in applying historical understanding to the present, it is time for the political science community (and social scientists more generally) to engage seriously with (neo) fascism studies. This journal will offer space for such an engagement.

\section{References}

Eatwell, Roger. "Introduction: the new extreme right challenge." In Western Democracies and the New Extreme Right Challenge. Eds. Roger Eatwell and Cas Mudde. London: Routledge, 2004, 1-16.

Williams, Michelle Hale. The Impact of Radical Right-Wing Parties in West European Democracies. New York: Palgrave Macmillan, 2006.

Stuart Woolf. "Introduction." In The Nature of Fascism. Ed. Stuart Woolf. London: Weidenfeld \& Nicolson, 1968. 